\title{
Diel variation in the ascent of fishes up an experimental fish ladder at Itaipu Reservoir: fish size, reproductive stage and taxonomic group influences
}

\author{
Domingo Rodriguez Fernandez*, Angelo Antonio Agostinho**, \\ Luis Mauricio Bini*** and Fernando Mayer Pelicice**
}

In this study, we evaluated the fish ascent in the experimental ladder at Itaipu Reservoir (Paraná State, Brazil), in relation to diel variation, fish size, reproductive stages and species composition. The study was carried out from October, 1995 to February, 1996 and from November, 1996 to January, 1997 at two points on the ladder (boxes at heights of 10 and 27 m). Twenty-two species were recorded, and Prochilodus lineatus, Pimelodus maculatus, Leporinus obtusidens, Schizodon borellii and Leporinus friderici accounted for $86.6 \%$ of the total catch. Fish length did not differ between diel periods and boxes. On the other hand, fish abundance of the main species was significantly influenced by box position, reproductive stage and diel period. The higher box showed lower abundance, suggesting some selectivity in ascension. The ability to ascend the ladder did not show any relationship with reproductive migration, since non-reproductive adults comprised most of the catch. An interesting finding is that the major taxonomic groups showed specific diel preferences in ascending the ladder: Characiformes ascended the ladder predominantly during daylight, whereas Siluriformes migrated at night. These results emphasize how complex ladders are as management tools, and stress the need to acquire information on several aspects as a condition to achieve conservation goals.

Nesse estudo, a transposição de peixes na escada experimental do reservatório de Itaipu (Paraná, Brasil) foi avaliada em relação à variação diária, tamanho dos peixes, estágios reprodutivos e a composição das espécies. O estudo foi conduzido de Outubro de 1995 a Fevereiro de 1996, e de Novembro de 1996 a Janeiro de 1997, em dois trechos da escada (caixas a 10 e 27 m de altura). Vinte e duas espécies foram registradas, e Prochilodus lineatus, Pimelodus maculatus, Leporinus obtusidens, Schizodon borellii e Leporinus friderici compuseram $86,6 \%$ das capturas. O tamanho dos peixes não diferiu entre os períodos do dia e caixas. Por outro lado, a abundância das principais espécies foi significativamente influenciada pela posição das caixas, estágio de reprodução e período do dia. A caixa superior tendeu a apresentar menor abundância de peixes, sugerindo certa seletividade na subida. A habilidade em ascender a escada não esteve relacionada com a migração reprodutiva, visto que adultos não-reprodutivos compuseram a maior parte das capturas. Um padrão interessante foi a preferência, apresentada pelos grandes grupos taxonômicos, por períodos específicos do dia na ascensão da escada: os Characiformes subiram a escada predominantemente durante o dia, enquanto os Siluriformes durante a noite. Esses resultados enfatizam o quão complexas são as escadas como ferramentas de manejo, e realçam a necessidade de ampliar o nível de informações sobre diversos aspectos como condição chave para que metas conservacionistas sejam alcançadas.

Key words: Fish migration, Fish passage, Selectivity, Non-reproductive fish, Management.

\footnotetext{
*Itaipu Binacional, Foz do Iguaçu, Paraná, Brazil.

**Universidade Estadual de Maringá, Departamento de Biologia, Nupelia, Av. Colombo 5790, Bloco H90, 87020-900 Maringá, Paraná, Brazil.agostinhoaa@gmail.com

***Universidade Federal de Goiás, ICB, Departamento de Biologia Geral, 74001-970 Goiânia, Goiás, Brazil.
} 


\section{Introduction}

Dams constitute obstacles to the free movement of fishes within a river system (Larinier, 2001). In addition to genetic consequences related to population fragmentation, the inability to reach spawning habitats and natural breeding areas severely affects fish recruitment, especially for migratory species (Agostinho et al., 2003). Depending on species requirements, the inaccessibility of critical habitats may result in complete recruitment failure.

The construction of fish ladders was proposed as a promising solution to such problems in the beginning of the $20^{\text {th }}$ century (Agostinho et al., 2004). In Brazil, the first ladder was constructed in 1911 at Itaipava Dam, Pardo River, a tributary of the Paraná River. In the 1920s, a second ladder (3 m high) was built at Cachoeira de Emas Dam (Mogi Guaçu River, Paraná River Basin) (Godoy, 1975; Quirós, 1988). Although several other ladders were constructed in the following decades, no study was carried out to evaluate their role as a conservation tool. As a result, the ineffectiveness of many facilities and their negative effects on fisheries and biodiversity have been demonstrated only recently (Agostinho et al., 2004; Agostinho et al., 2005). For example, the ladder at Cachoeira de Emas Dam was considered a model of efficiency in the Brazilian literature, but it was too small to be a useful model for the large dams built after 1950. Likewise, Godinho et al. (1991) point out the low efficiency of the ladder built at Salto Morais Dam (Tijuco River, Upper Paraná River Basin) for the passage of migratory species, and Fernandez et al. (2004) emphasize the same negative aspect for the experimental ladder built at Itaipu Reservoir. Agostinho et al. (2007b) present a similar picture for the ladder built at Lajeado Dam, Tocantins River.

The lack of consistent information is responsible for the controversy surrounding this subject among decision-makers and researchers in Brazil (Britski, 1994; Agostinho et al., 2002). Except for the preliminary results obtained at Itaipu Dam (Borghetti et al., 1993, 1994), and a few recently published studies (Fernandez et al., 2004; Vono et al., 2004; Britto \& Sirol, 2005), the ability of fishes in the Paraná River Basin to overcome the obstacles posed by the height, flow or design of ladders is poorly known. Therefore, this study contributes new information on aspects of fish passage in the step-type ladder built near the Itaipu Dam. We explored the ability of the dominant species and taxonomic groups to ascend the facility, investigating aspects related to fish length and reproductive stages, and compared the ascension of fishes during different diel periods.

\section{Material and Methods}

\section{Study area}

The fish ladder analyzed in the present study was built by the Environmental and Engineering Department of Itaipu Binacional, as part of an experimental project addressing the migratory channel (Canal da Piracema) located downstream from Itaipu Dam. The ladder (a step-type) is $155 \mathrm{~m}$ long and 27 $\mathrm{m}$ high. Because this ladder was experimental, all fishes reaching the highest stretch were returned to the river, downstream from the dam. A detailed description of the ladder can be found in Fernandez et al. (2004).

\section{Fish Sampling}

Samples were taken over a 24-hour period (14:00, 20:00, 02:00 and 08:00 h), monthly from October, 1995 to February, 1996 and from November, 1996 to January, 1997 (peak migratory season). Samples were obtained at two stretches on the ladder. The first stretch, designated hereafter as box A $(3.5 \mathrm{x}$ $3.5 \times 0.8 \mathrm{~m}$ ), was located in the second still-water resting pool, $40 \mathrm{~m}$ from the entrance of the structure, at an average height of $10 \mathrm{~m}$ above the Paraná River. The second stretch, named box B $(5.0 \times 5.0 \times 0.8 \mathrm{~m})$, was situated in the fourth still-water resting pool, $155 \mathrm{~m}$ from the ladder entrance, with an average height of $27 \mathrm{~m}$ (Fig. 1).

Fish samples were taken using a dip net with a mesh of 1.5 $\mathrm{cm}$ between opposite knots and a rectangular frame of $1.0 \mathrm{x}$ $0.5 \mathrm{~m}$. In each box, an effort of three minutes per catch was applied. The analyses of the samples, including species identification, total and standard lengths, determination of sex and stage of gonadal development were carried out in a laboratory installed at the site. Individuals were classified as immature (juveniles), non-reproductive adult (resting, maturation or spent gonads) and mature (ripe and semi-spent gonads).

\section{Statistical Analysis}

To test if fish size varied in relation to diel period and box location, a two-way analysis of variance (ANOVA) was performed for the most abundant species, considering diel pe$\operatorname{riod}(02: 00,08: 00,14: 00$ and 20:00 h) and box (A and B) as factors.

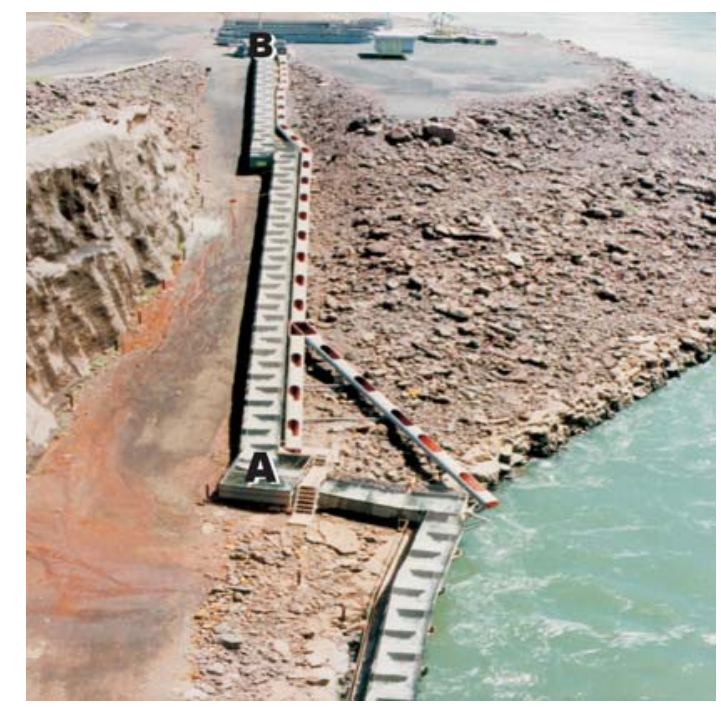

Fig. 1. The experimental fish ladder located at Itaipu Dam. Sampling stations are indicated in the figure $(A=$ box $A ; B=$ box $B)$. 
Log-linear modeling was applied to verify if the probability of capture (abundance) varied due to diel period, box location and reproductive stages (immature, mature and non-reproductive adults) for each of the most abundant species. After identifying the factors and the interactions between them that most significantly affected the catches, the goodness-of-fit of the model, considering the significant effects, was evaluated by the log-likelihood chi-square statistic (Manly, 1994). The same analysis was done to verify if the probability of capture in the ladder varied between the main taxonomic categories (Characiformes and Siluriformes), considering also the influence of diel period and box location.

Statistical significance for all analyses implied an $\mathrm{P} \leq 0.05$, and parametric assumptions (normality and homoscedasticity) were checked prior to analysis.

\section{Results}

Twenty-two species were recorded at the low (box A) and high (box B) sampling stretches of the ladder. The main species captured were Prochilodus lineatus, Pimelodus maculatus, Leporinus obtusidens, Schizodon borellii and Leporinus friderici, accounting for $86.6 \%$ of total abundance (Table 1). In general, males were more frequent than females.

Fish length did not differ significantly between boxes and diel period for the three main species (Table 2). A significant interaction (diel period*box) was detected for $L$. friderici, since larger individuals were caught at $14: 00 \mathrm{~h}$ (mainly in box A) and smaller ones at 20:00 h (Fig. 2). Schizodon borellii showed significant differences between diel periods only, with smaller individuals recorded at 20:00 $\mathrm{h}$ in both boxes.

Table 1. Fish species captured in the experimental ladder at Itaipu Dam. The table shows the number of individuals captured $(\mathrm{N})$ and the mean standard length $(\mathrm{Ls} \pm$ standard deviation - SD).

\begin{tabular}{lcccc}
\hline Species & $\begin{array}{c}\text { Males } \\
(\mathrm{N})\end{array}$ & $\begin{array}{c}\text { Females } \\
(\mathrm{N})\end{array}$ & $\begin{array}{c}\text { Total } \\
(\mathrm{N})\end{array}$ & $\begin{array}{c}\text { Ls-Mean } \pm \text { SD } \\
(\mathrm{cm})\end{array}$ \\
\hline Prochilodus lineatus & 100 & 65 & 165 & $40.43 \pm 3.67$ \\
Pimelodus maculatus & 129 & 27 & 156 & $24.76 \pm 2.98$ \\
Leporinus obtusidens & 98 & 43 & 141 & $30.01 \pm 7.22$ \\
Schizodon borellii & 55 & 67 & 122 & $26.29 \pm 3.23$ \\
Leporinus friderici & 45 & 32 & 77 & $21.40 \pm 5.19$ \\
Astyanax altiparanae & 14 & 16 & 30 & $8.61 \pm 0.92$ \\
Pterodoras granulosus & 11 & 17 & 28 & $37.89 \pm 5.84$ \\
Roeboides paranensis & 3 & 8 & 11 & $16.71 \pm 1.75$ \\
Iheringichthys labrosus & 4 & 2 & 6 & $14.72 \pm 1.79$ \\
Rhaphiodon vulpinus & 4 & 1 & 5 & $39.38 \pm 2.23$ \\
Acestrorhynchus lacustris & 3 & 0 & 3 & $14.17 \pm 1.26$ \\
Sorubim lima & 3 & 0 & 3 & $34.33 \pm 3.74$ \\
Hemisorubim platyrhynchos & 1 & 3 & 4 & $42.53 \pm 6.71$ \\
Oxydoras kneri & 3 & 0 & 3 & $39.47 \pm 9.04$ \\
Pimelodus ornatus & 1 & 1 & 2 & $17.45 \pm 0.07$ \\
Pseudopimelodus mangurus & 0 & 1 & 1 & 23.60 \\
Hypostomus sp. & 1 & 0 & 1 & 15.00 \\
Apareiodon affinis & 0 & 1 & 1 & 14.00 \\
Salminus brasiliensis & 1 & 0 & 1 & 37.50 \\
Hemiodus orthonops & 0 & 1 & 1 & 17.20 \\
Pinirampus pirinampu & 0 & 1 & 1 & 39.00 \\
Pimelodus sp. & 1 & 0 & 1 & 15.20 \\
\hline & & & & \\
\hline
\end{tabular}

In relation to captures, abundance of the main species in the ladder was significantly influenced by diel period, stage of maturation and box position (Table 3). In general, for the four most abundant species, box A tended to show higher abundance, mainly of non-reproductive adults (Fig. 3).

For "curimba" P. lineatus, all factors affected significantly the frequency of ascension, including an interaction between diel period and box (Table 3). Non-reproductive adults were significantly more captured, and box A tended to show higher abundance (Fig. 3). The log-linear model, considering the interaction among diel period, box and reproductive stage, adequately fitted to the data $\left(\chi^{2}=5.09 ; \mathrm{df}=14 ; P=0.98\right)$, suggesting that these factors satisfactorily predict the abundances observed.

Higher captures of "mandi" P. maculatus were observed in box $\mathrm{A}$ at night, and non-reproductive adults were significantly more frequent (Table 3; Fig. 3). The interaction diel period*box was significant, because the high abundance recorded in box B at 02:00 h (Fig. 3). The frequencies estimated by the log-linear model, considering the interaction among all factors, did not significantly differ from the observed frequencies $\left(\chi^{2}=15.14 ; \mathrm{df}=14 ; P=0.37\right)$. At the $5 \%$ level, only one residual was significantly higher than zero (2.73).

The captures of "piapara" L. obtusidens were significantly influenced by all factors (Table 3 ). These fishes were caught mainly during the day in box A, basically non-reproductive adults (Fig. 3). The best-fitted model considered the isolated effects of each factor plus the interaction between diel period and reproductive stage $\left(\chi^{2}=12.25 ; \mathrm{df}=11 ; P=0.34\right)$.

Table 2. Two-way analysis of variance (ANOVA) evaluating the effect of diel period (time) and box (position in the ladder) on the standard length of the main species.

\begin{tabular}{lcccccc}
\hline & \multicolumn{2}{c}{ Time } & \multicolumn{2}{c}{ Box } & \multicolumn{2}{c}{ Interaction (time*box) } \\
\cline { 2 - 7 } \multicolumn{1}{c}{ Species } & $\mathrm{F}$ & $\mathrm{P}$ & $\mathrm{F}$ & $\mathrm{P}$ & $\mathrm{F}$ & $\mathrm{P}$ \\
\hline P. lineatus & 1.76 & 0.1579 & 0.09 & 0.7623 & 1.73 & 0.1625 \\
P. maculatus & 0.75 & 0.5243 & 1.39 & 0.2396 & 1.94 & 0.1250 \\
L. obtusidens & 0.35 & 0.7872 & 2.13 & 0.1463 & 0.66 & 0.5764 \\
S. borellii & 5.40 & 0.0016 & 0.08 & 0.7758 & 1.27 & 0.2868 \\
L. friderici & 1.85 & 0.1470 & 0.57 & 0.4523 & 4.74 & 0.0045 \\
\hline
\end{tabular}

Table 3. Values for $\chi^{2}$ statistics evaluating the effect of diel period (1), box (2) and reproductive stages (3) on the abundance of the main species. Significance levels are indicated between parentheses.

\begin{tabular}{cccccc}
\hline & P.lineatus & P.maculatus & L.obtusidens & S.borellii & L. friderici \\
\hline \multirow{2}{*}{1} & 18.6 & 25.37 & 40.64 & 16.66 & 16.40 \\
& $(<0.001)$ & $(<0.001)$ & $(<0.001)$ & $(<0.001)$ & $(<0.001)$ \\
2 & 14.7 & 5.38 & 23.35 & 20.72 & 3.27 \\
& $(<0.001)$ & $(0.020)$ & $(<0.001)$ & $(<0.001)$ & $(0.070)$ \\
3 & 70.2 & 159.41 & 120.85 & 100.91 & 39.11 \\
& $(<0.001)$ & $(<0.001)$ & $(<0.001)$ & $(<0.001)$ & $(0.000)$ \\
$1 \times 2$ & 14.0 & 14.11 & 4.64 & 30.32 & 5.15 \\
& $(0.003)$ & $(0.003)$ & $(0.200)$ & $(0.000001)$ & $(0.161)$ \\
$1 \times 3$ & 1.1 & 8.25 & 10.15 & 2.68 & 4.04 \\
& $(0.780)$ & $(0.220)$ & $(0.118)$ & $(0.847)$ & $(0.671)$ \\
$2 \times 3$ & 0.01 & 2.45 & 2.54 & 0.02 & 0.68 \\
& $(0.928)$ & $(0.293)$ & $(0.281)$ & $(0.989)$ & $(0.710)$ \\
\hline
\end{tabular}



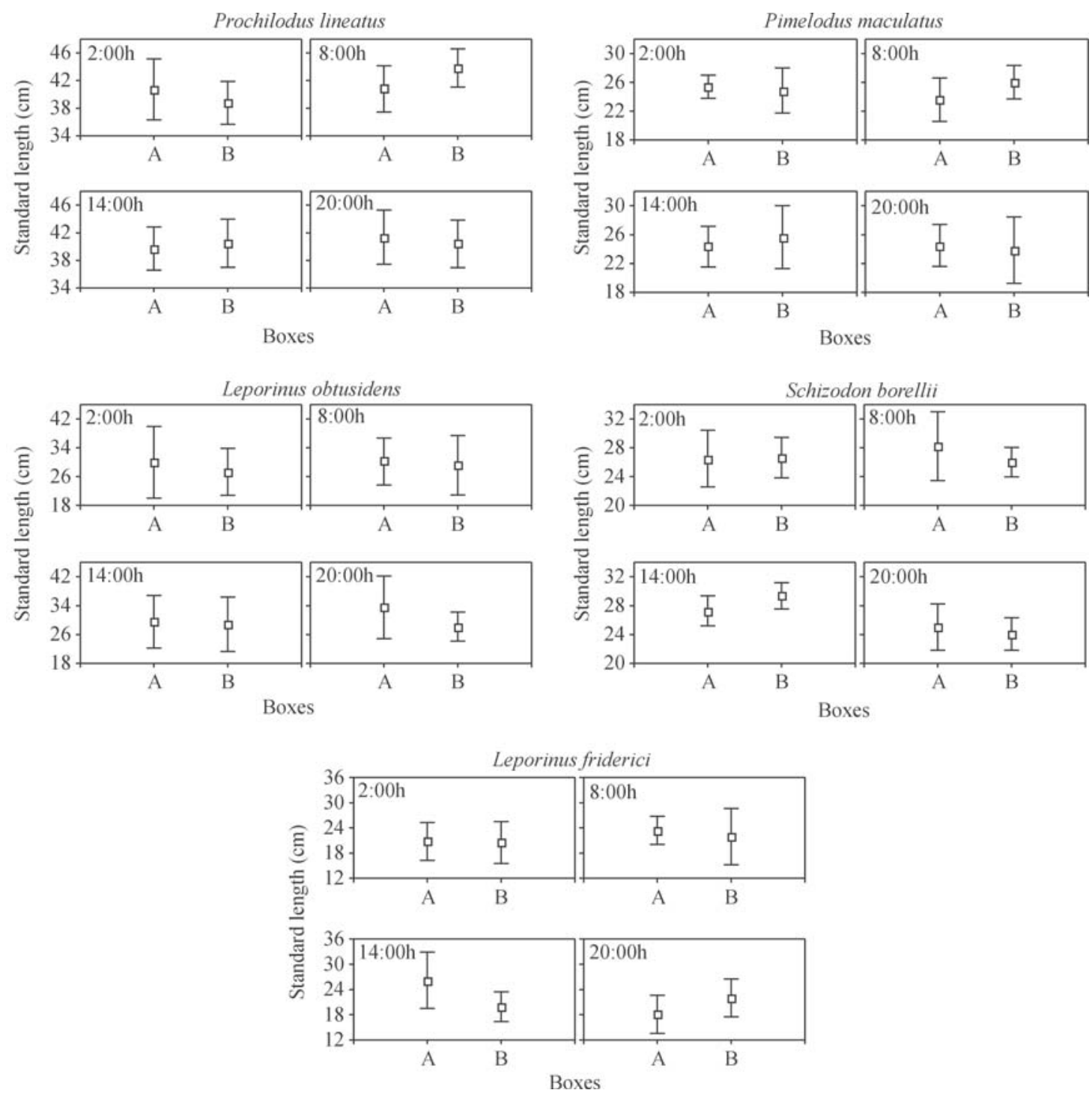

Fig. 2. Variation in mean standard length of the most abundant species recorded in the fish ladder (box $A=10 \mathrm{~m}$; box $B=27 \mathrm{~m}$ ).

All factors affected the probability of capturing "piava" S. borellii. Moreover, the interaction between diel period and box was also significant (Table 3). In general, higher captures were observed in box A at 14:00 and 20:00 h, with predominance of non-reproductive adults (Fig. 3). The loglinear model that considered the interaction between diel period and box, plus the isolated effect of the reproductive stage, fitted to the data satisfactorily $\left(\chi^{2}=9.55 ; \mathrm{df}=14 ; P=0.79\right)$.

For "piau" $L$. friderici, only the effects of diel period and reproductive stage were significant (Table 3). Most individuals were captured at 14:00 and 20:00 h, mainly nonreproductive adults (Fig. 3). The log-linear model that considered these factors fitted to the data satisfactorily $\left(\chi^{2}=19.57 ; \mathrm{df}=18 ; P=\right.$ 0.36 ); however, two standardized residuals were greater than 2 (significantly different from zero at the $5 \%$ level). For the remaining species (17), it is interesting to point out that about $70 \%$ of captures occurred in box A, particularly at $02: 00 \mathrm{~h}$.

Concerning taxonomic groups, Characiformes showed higher abundance throughout the entire diel cycle in both boxes, except at dawn, when Siluriformes catches were similar (Fig. 4). This group showed minor differences in catches between boxes, although both groups tended to be less abundant in box B. Only the log-linear model that considered the interaction between taxonomic order, diel period and box resulted in an insignificant value of $\chi^{2}$. This model is saturated in the sense that it has as many parameters as frequencies, which makes it less informative. Successive analyses with the inclusion of the factors studied, however, indicated significant improvements in fitting (Table 4).

\section{Discussion}

Fish ladders are complex management tools, designed primarily to conserve migratory fish stocks under the influence of impoundments (Larinier, 2001). To perform efficiently and accomplish conservation goals, their construction require 

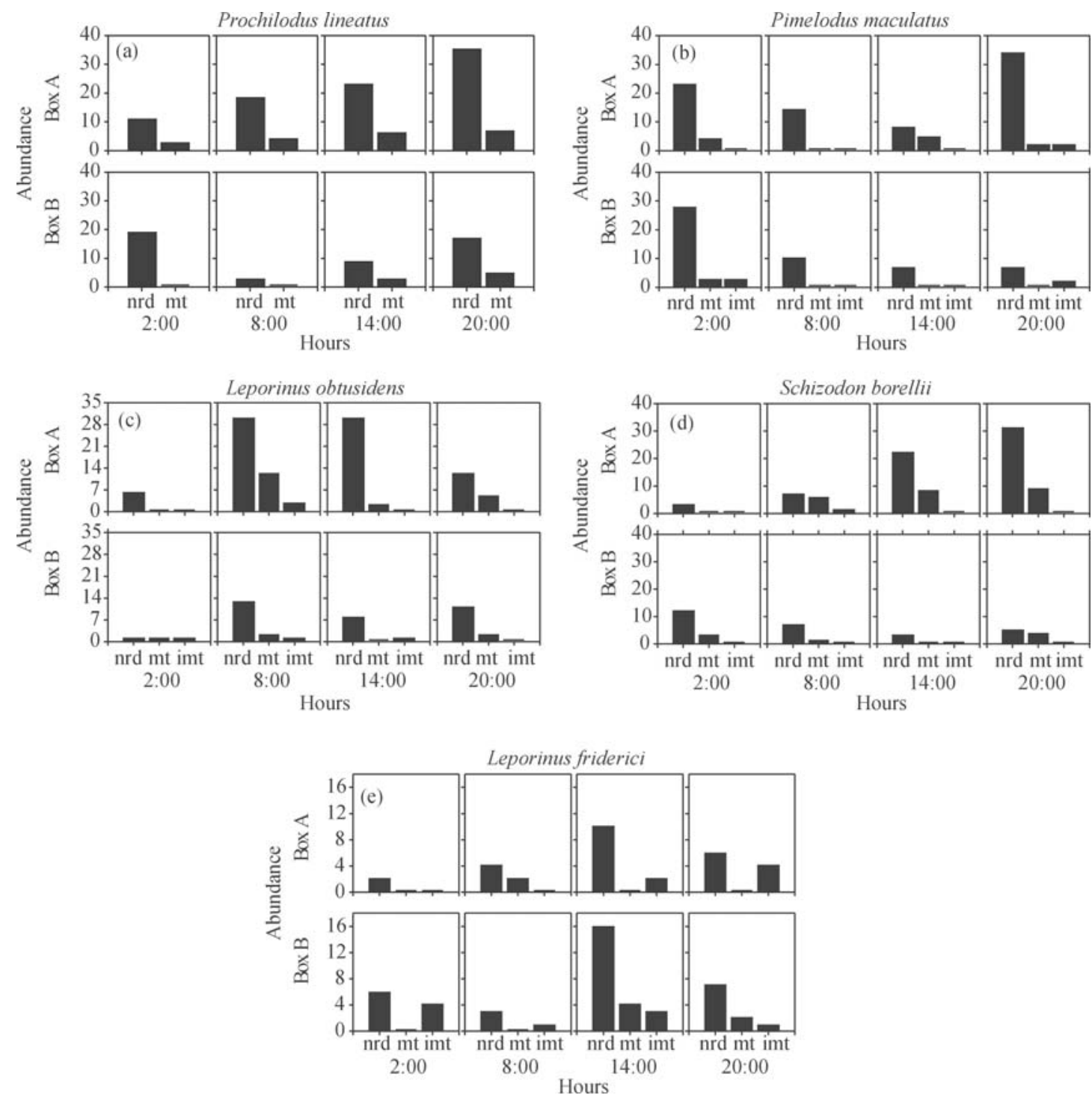

Fig. 3. Diel variation in the number of individuals of the five main species, sampled at two different points in the ladder (Box A and B). Reproductive stages: non-reproductive adults (nrd), mature (rd), and immature (imt). Species: (a) Prochilodus lineatus; (b) Pimelodus maculatus; (c) Leporinus obtusidens; (d) Schizodon borellii; (e) Leporinus friderici.

Table 4. Values of $\mathrm{c}^{2}{ }_{\mathrm{L}}$ statistics evaluating the effects of taxonomic group (1), diel period (2) and box position (3) on fish abundance in the ladder.

\begin{tabular}{cccc}
\hline Factors & df & $\chi^{2}$ & $P$ \\
\hline 1 & 1 & 173.03 & $<0.001$ \\
2 & 3 & 14.11 & 0.002 \\
3 & 1 & 46.37 & $<0.001$ \\
$1 \times 2$ & 3 & 83.17 & $<0.001$ \\
$1 \times 3$ & 1 & 0.097 & 0.755 \\
$2 \times 3$ & 3 & 25.63 & $<0.001$ \\
\hline
\end{tabular}

information on several aspects related to fish biology and ecology, environmental surroundings and hydrodynamics. However, because fish passage mechanisms were historically built simply as bureaucratic essentialities in Brazil, these facilities are characterized by failures in several aspects, and their role in fish conservation still needs empirical demonstration (Agostinho et al., 2004; Agostinho et al., 2007a).

The few studies carried out in Brazilian waters have shown that ladders differ remarkably in their efficiency to pass fish above the dam (Godinho et al., 1991; Fernandez et al., 2004; Agostinho et al., 2007b). In relation to taxonomic groups, the present results clearly showed that Characiformes are more abundant than Siluriformes in the ladder. The predominance of Characiformes is expected, since these fishes have a greater swimming potential (Agostinho et al., 2003). Yet, analyzing two different stretches in the ladder showed that, although low selectivity exists for fish size, significantly fewer fish were captured in the pool located farther from the entrance (box B). This result strongly suggests that fish abundance decreases progressively along the facility, a pattern well described in the ladder built at Lajeado Dam (Agostinho et al., 2007b). If 

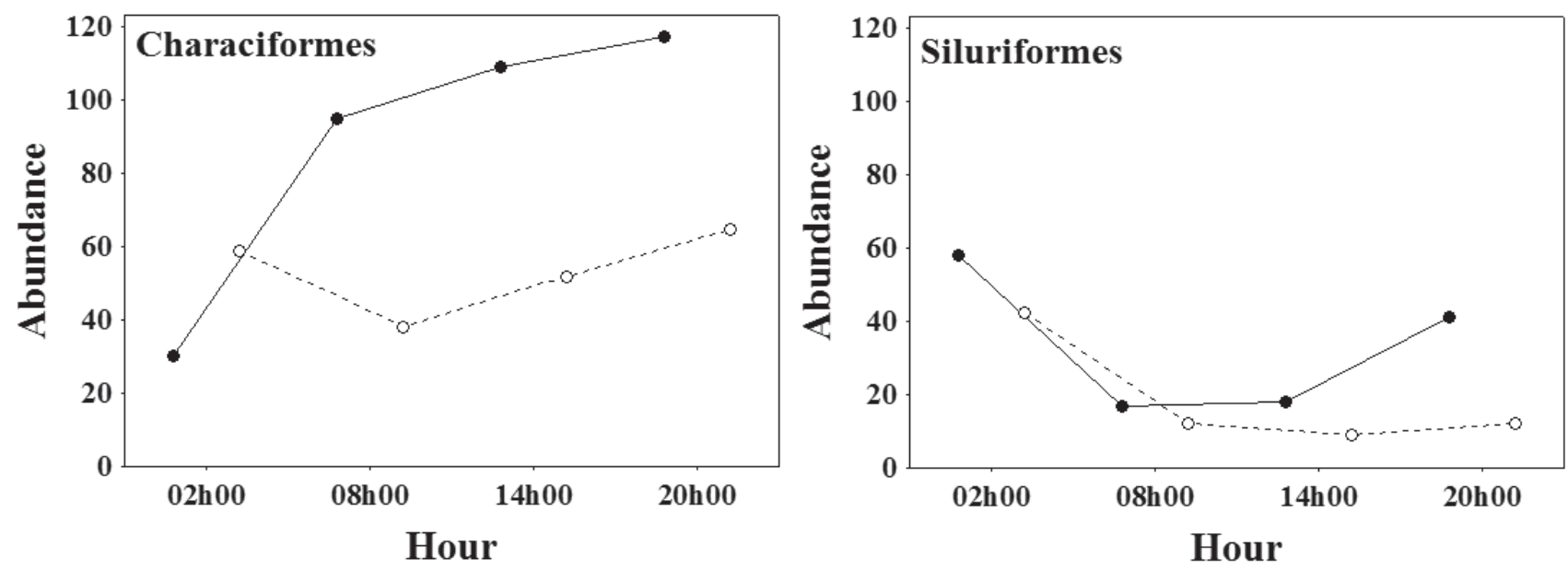

Fig. 4. Diel variation in the abundance of Characiformes and Siluriformes sampled at box A (10 m height; closed circles) and B ( $27 \mathrm{~m}$ height; open circles) in the ladder.

such selective passage is prolonged for years, population imbalances may arise, especially if fishes are performing unidirectional movements (usually upward; Agostinho et al., 2004).

A previous study carried out monthly from November, 1994 to February, 1997 in the ladder at Itaipu (Fernandez et al., 2004) recorded the presence of 27 fish species ascending the facility at daytime (14:00 to $16: 00 \mathrm{~h}$ ). In the present study, the most abundant species in the $24 \mathrm{~h}$ samplings were the same detected by Fernandez et al. (2004), suggesting that these species conspicuously ascend this ladder. However, some economically important species, which have a conspicuous migratory behaviour, had very low occurrence or were absent in the ladder, such as Salminus brasiliensis and Pseudoplatystoma corruscans. In addition, the usual presence of some species may not be related to successful reproductive activity and the conservation of stocks.

For example, the pattern of fish ascension failed to show a relationship with reproductive migration for the most abundant species, especially large migratory species. Even though samplings occurred during the reproductive period (October-March; Vazzoler, 1996), and the five most abundant species had an average length larger than the size at first maturation, fishes with gonads in the pre-vitellogenic phase (nonreproductive) predominated in the ladder. Although Godoy (1967) reports that maturing individuals predominate within shoals undertaking migration, our results suggest that the stimulus to enter and ascend the ladder may have a diverse nature. It is likely that the water flow and turbulence created by the ladder have a significant effect attracting fish nearby the facility, mainly rheophilic species. Godinho et al. (1991) also reported the concomitant presence of larvae, juveniles and adults of migratory species on the ladder located at Salto Moraes Dam. Therefore, if shoals of non-reproductive fish prevailed using the facility at Itaipu, its role as a way to allow reproductive migration is very doubtful. It is important to discover if reproductive migratory fishes downstream of Itaipu Dam are wasting their reproductive effort and reabsorbing their gonads (Agostinho et al., 1993), or if these fishes are moving to other areas (Antonio, 2006). Agostinho et al. (2007c), in this volume, also reported a high frequency of individuals (98\%) with gonads in the pre-vitellogenic stage in the fish ladder, and concluded that there was no reproductive motivation for fish to ascend the passage. Mark-recapture studies or radio-telemetry methods would help to elucidate migratory routes in the region and how migratory fish are responding to the ladder. Such studies may determine precisely if reproductive fishes avoid the ladder and travel to other areas below Itaipu Dam, or if they spend a long time in finding the entrance of the ladder, after which the reproductive effort is lost.

Godoy (1975) reports that the displacements of migratory species during their reproductive migrations show similar intensities during day-night periods, but we found a significant effect of diel period on fish movement in the ladder. Individuals were captured throughout the day, but trends in abundance suggest that some species (and even higher taxonomic groups) have preferential periods for performing upward movements. For example, Characifomes tended to migrate mostly during the day, whereas Siluriformes performed nocturnal migrations. The nocturnal behavior of Siluriformes has already been reported in the literature (Lowe-McConnell, 1987), but the diel behavior of Neotropical fish in ladders still lacks empirical observations. Pompeu \& Martinez (2006) report similar results for the fish lift incorporated at Santa Clara Dam (Mucuri River). It is important to point out that daily periodicity in fish movements is a worldwide phenomenon, and light levels seem to play a significant role in motivating fish displacements (Lucas \& Baras, 2001). This finding is paramount to determining diel cycles of functioning of ladders 
and to maximize their efficiency. If the facility remains open for specific diel periods, it is likely that selectivity will increase for some taxonomic group. Therefore, managers must seriously consider this diel effect when planning the operation of ladders.

The effect of diel periodicity on fish movement patterns may be much more complex. For example, Oncorhynchus masou juveniles showed (on an experimental fish ladder) ascending activity mainly during the day; however, when stimulated by an increase in flow, the fishes also ascended at night (Mayama, 1987). In the present study, smaller individuals of L. friderici and $S$. borellii showed trends of ascending the ladder preferentially at dusk, while larger individuals displayed activity during the day. These tendencies are still a source of controversy in the literature, suggesting that ascending stimulus related to light conditions also depends on several other factors, including the size of the individual and reproductive stage. To clarify such dynamics, the evaluation of fish diel activity in other fish passages is urgently needed.

The hydraulic design of the experimental fish ladder at Itaipu is able to attract Characiformes and Siluriformes, but selectivity on abundance occurs along the ladder (Fernandez et al., 2004), and we showed some biological factors related to diel selectivity. Species showed preferential periods of activity for ascending the device, which suggests that special management protocols are required to maximize the migration of several species, such as the need for day-night operation cycles and the determination of preferable flow velocities for each fish group. Obviously, if dam operation procedures (e.g., discharge control for hydroelectricity or spillway releases) take into account the diel activity of ascending fishes, selectivity in passage systems could be importantly reduced (Lucas $\&$ Baras, 2001). However, our results also showed that most migrating individuals are not carrying out reproductive migration, seriously doubting the primary role of the ladder (a corridor to allow the continuity of reproductive displacements, and therefore, the opportunity to complete the life cycle). Considering these aspects and all impacts that may take place when ladders are indiscriminately constructed (Agostinho et al., 2004), it is clear that fish ladders should not be considered an end in themselves. Rather, they should be viewed as an operational management tool based on a complete spatialtemporal understanding of fish populations, taking into consideration the nature of the ichthyofauna and the ecosystem in which they are inserted. Thus, the success of this endeavor demands effort and considerable knowledge of the system to be managed, and it occurs only when recruitment is completed.

\section{Literature Cited}

Agostinho, A. A., L. C. Gomes, D. R. Fernandez \& H. I. Suzuki. 2002. Efficiency of fish ladders for neotropical ichthyofauna. River Research and Applications, 18: 299-306.

Agostinho, A. A., L. C. Gomes \& J. D. Latini. 2004. Fisheries management in Brazilian reservoirs: Lessons from/for South America. Interciencia, 29(6): 334-338.
Agostinho, A. A., L. C. Gomes, H. I. Suzuki \& H. F. Júlio Jr. 2003. Migratory fish from the upper Parana river basin, Brazil. Pp. 19-98. In: Carolsfeld J., B. Harvey, C. Ross \& A. Baer (Eds). Migratory fishes of South America: biology, social importance and conservation status. Victoria, World Fisheries Trust, The World Bank and The International Development Research Centre.

Agostinho, A. A., E. E. Marques, C. S. Agostinho, D. A. Almeida, R. J. de Oliveira \& J. R. B. de Melo. 2007a. Fish ladder of Lageado Dam: migrations or on one way routes? Neotropical Ichthyology, 5(2): 121-130.

Agostinho, A. A., V. P. Mendes, H. I. Suzuki \& C. Canzi. 1993. Avaliação da atividade reprodutiva da comunidade de peixes dos primeiros quilômetros a jusante do Reservatório de Itaipu. Revista UNIMAR, 15: 175-189.

Agostinho, A. A., S. M. Thomaz \& L. C. Gomes. 2005. Conservation of the biodiversity of Brazil's inland waters. Conservation Biology, 19: 646-652.

Agostinho, C. S, A. A. Agostinho, F. M. Pelicice, D. A. Almeida, E. E. Marques. 2007b. Selectivity of fish ladders: a bottleneck in Neotropical fish movement. Neotropical Ichthyology, 5(2): 205213.

Agostinho, C. S., C. R. Pereira, R. J. Oliveira, I. S. Freitas \& E. E. Marques. 2007c. Movements through a fish ladder : temporal patterns and motivations to move upstream. Neotropical Ichthyology, 5(2): 161-167.

Antonio, R. R. 2006. Movimentos ascendentes e descendentes de grandes peixes migradores a partir de uma barragem hidrelétrica sem mecanismos de transposição. Monografia. Curso de Especialização em Biologia Aquática. Maringá, Universidade Estadual de Maringá, 20p.

Borghetti, J. R., D. P. Chena \& S. V. G. Nogueira. 1993. Installation of a fish migration channel for spawning at the Itaipu hydroelectric power station. Water Power and Dam Construction, 5: 24-25.

Borghetti, J. R., S. V. G. Nogueira, N. R. B. Borghetti \& C. Canzi. 1994. The fish ladder at the Itaipu Binational hydroelectric complex on the Paraná River, Brazil. Regulated Rivers: Research and Management, 9: 129-130.

Britski, E. A. 1994. As bacias hidrográficas e a preservação da biodiversidade. Seminário sobre fauna aquática e o Setor Elétrico Brasileiro. Eletrobrás, Caderno 1, Rio de Janeiro, Pp. 30-37.

Britto, S. G. C. \& R. N. Sirol. 2005. Transposição de peixes como forma de manejo: as escadas do complexo Canoas, médio Paranapanema, bacia do Alto Paraná. Pp. 285-304. In: Nogueira, M. G., R. Henry \& A. Jorcin (Eds). Ecologia de reservatórios: impactos potenciais, ações de manejo e sistemas em cascata. São Carlos, Rima.

Fernandez, D. R., A. A. Agostinho \& L. M. Bini. 2004. Selection of an experimental fish ladder located at the dam of the Itaipu Binacional, Brazil. Brazilian Archives of Biology and Technology, 47(4): 579-586.

Godinho, H. P., A. L. Godinho, P. S. Formaggio \& V. C. Torquato. 1991. Fish ladder efficiency in a southeastern Brazilian river. Ciência e Cultura, 43: 63-67.

Godoy, M. P. 1967. Dez anos de observação sobre a periodicidade migratória de peixes do rio Mogi Guaçu. Revista Brasileira de Biologia, 27: 1-12.

Godoy, M. P. 1975. Peixes do Brasil, Subordem Characoidei, Bacia do rio Mogi Guassu. Pirassununga, Editora Franciscana, 4v.

Larinier, M. 2001. Environmental issues, dams and fish migration. Pp. 45-89. In: Marmulla, G. (Ed.). Dams, fish and fisheries: 
opportunities, challenges and conflict resolution. FAO Fisheries Technical Paper 419, Rome.

Lowe-McConnell, R. 1987. Ecological studies in tropical fish communities. London, Cambridge University Press, 382p.

Lucas, M. C. \& E. Baras. 2001. Migration of freshwater fishes. Oxford: Blackwell Science, 420p.

Manly, B. F. J. 1994. The design and analysis of research studies. Cambridge, Cambridge University Press, 353p.

Mayama, H. 1987. Ascending behavior of juvenile masu salmon (Oncorhyncus masou) in experimental fishway. Scientific Report of the Hokkaido Salmon Hatchery, 41: 137-153.

Pompeu, P. dos S. \& C. B. Martinez. 2006. Temporal patterns of fish passage in Santa Clara Power Plant's fish lift, Mucuri River, east Brazil. Revista Brasileira de Zoologia, 23(2): 340-349.

Quirós, R. 1988. Structures assisting migrations of fish other than Salmonids: Latin America. Rome, FAO-COPESCAL, Food and Agriculture Organization of the United Nations.

Vazzoler, A. E. A. M. 1996. Biologia e reprodução de peixes teleósteos: teoria e prática. Maringá EDUEM, 169p.

Vono, V., P. M. Bizzotto, H. P. Godinho, A. L. Godinho \& B. Kynard. 2004. Fish passage at the Igarapava fish ladder, Rio Grande, Brazil, Pp. 1-5. In: Annals of the International Congress on the Biology of Fish - Tropical Hotel Resort. Manaus, American Fisheries Society.

Received January 2007

Accepted June 2007 